\title{
Revitalizing property of banana peel extracts by antioxidant activity and antibacterial activity against acne causing Staphylococcus epidermidis
}

\author{
P. Saravana Kumari*, R. Ranjitha* and N. Vidhya** \\ Department of Microbiology, Rathnavel Subramaniam College of Arts and Science, Sulur, Coimbatore-641402, Tamilnadu, India \\ *PG and Research Department of Microbiology, Sree Narayana Guru College, Coimbatore-641105, Tamilnadu, India \\ **Department of Microbiology, Dr. NGP Arts and Science College, Coimbatore-641048, Tamilnadu, India
}

\section{Article Info}

Article history

Received 1 September 2020

Revised 23 October 2020

Accepted 25 October 2020

Published online 30 December 2020

\section{Keywords}

Banana peel

Bioautography

Antioxidant activity

Acne

Biosorption

\begin{abstract}
Acne vulgaris is a common skin inflammatory lesion caused by the bacteria, Propionibacterium acnes, Staphylococcus epidermidis and Malassezia furfur in the follicular canal of the epidermal layer of skin. In order to combat the problem, Propionibacterium acnes and Staphylococcus epidermidis are the target for many antiacne drugs. Increasing awareness towards the use of organic based products paved the way to search for medicines from banana peel. In vitro antibacterial activity of acetone extract of banana fruit peel from Musa sapientum investigated on isolated species of acne causing Staphylococcus epidermidis by agar well diffusion technique and minimal inhibitory concentration (MIC). Antioxidant activity assayed for the extract by DPPH and ABTS assay methods. Active principle in the extract was separated by analytical and preparative TLC and its antibacterial activity assayed against the pathogen. Maximum antibacterial activity of acetone extract against Staphylococcus epidermidis recorded as $17 \mathrm{~mm}$ in diameter, the MIC of the acetone extract recorded as $32 \mu \mathrm{g} / \mathrm{ml}$ and banana fruit peel powder showed $70 \%$ of sorption of pathogen. Phytochemical analysis showed the presence of $31.56 \pm 0.21 \mathrm{mg}$ gallic acid equivalent of phenols/g of dry banana peel extract and maximum antioxidant activity of $71.21 \pm 0.91$ and $86.78 \pm 0.88$ and $\mathrm{IC}_{50}$ as $36.2 \%$ and $44.6 \%$ by DPPH and ABTS methods, respectively. Further assays confirmed the presence of phenolics, alkaloids, saponins and lipid peroxidase. As banana peel is having biosorption property, high biocompatible phenolics, antibacterial alkaloids and free radical scavenging activity, recommended for facial application to control acne causing Staphylococcus epidermidis.
\end{abstract}

\section{Introduction}

Acne vulgaris is a common skin disease of pilosebaceous gland, which affects areas containing the largest oil glands includes the skin surface of the face, back, and trunk. It is generally characterized by formation of seborrhea, come-done that leads to inflammatory lesions by the normal flora Propionibacterium acnes, Staphylococcus epidermidis and Malassezia furfur in the follicular canal and leads to sebum production. Commonly, Propionibacterium acnes described as an obligate anaerobic bacteria. It is associated with the development of inflammatory acne by activating complement cascade on the skin. Whereas another inflammation causing bacteria, Staphylococcus epidermidis is an aerobic organism, usually cause superficial infections within the sebaceous unit and also induce inflammation. In order to control the infection and inflammation on the skin surface, Propionibacterium acnes and Staphylococcus

Corresponding author: Dr. P. Saravana Kumari Associate Professor, Department of Microbiology, Rathnavel Subramaniam College of Arts and Science, Sulur, Coimbatore-641402, Tamilnadu, India

E-mail: sarankumaribs@gmail.com

Tel.: +91-9442386269

Copyright (C) 2020 Ukaaz Publications. All rights reserved.

Email: ukaaz@yahoo.com; Website: www.ukaazpublications.com epidermidis are the target for currently used chemical antiacne drugs. In many instances, medication fails to treat due to the long term usage results in aggravated side effects on the face and development of drug resistance by the pathogens. To overcome these problems, medicinal plants have been extensively studied as an alternative to treatment as it has different methods in control of pathogens and inflammatory response. Different parts of the plant extract traditionally know for microbial control now proven as effective in controlling the microbial infections. Secondary metabolites of the plants produced in micromolar concentrations that offers plant endurance, microbial resistance, stress resistance and extensive defense towards predation and these bioactive phytochemical components purified, characterized and commercialized in food, feed and pharmaceutical industries as they derived from traditionally used edible plants and plant parts (Upadhyay et al., 2014). Ethanolic flower extract of Rhododendron arboreum confirmed with both antioxidant and antimicrobial activity against potent infectious agents and so, recommended in the food industry as a preservative (Kashyap et al., 2017). The outer cover or fruit peel of the fruits protects the fruit from environment, micro, and macro organisms as it analyzed contain essential oil, phenolic, phenolic acids (benzoic and cinnamic acid derivatives), glycosides, lignans, lignins, anthocyanins, flavonolignans, flavonoids, coumarins, stilbenes, triterpenoids, tannins, 
ellagitannins, vitamin C, and carotenoids. These compounds have strong antioxidant properties, antitumoral, antiviral, antibacterial, cardio-protective, and antimutagenic activities. The exploitation of fruit peels as a source of functional compounds for treatment of disease is the bottleneck of the medical research (Pathak, 2020). In the present study, biocompatible waste, banana fruit peel examined for control of most common acne inflammation causing organisms, Staphylococcus epidermidis by antibacterial activity, biosorption and antioxidant activity.

The banana is a monocot plant grown worldwide and ripe fruit very often consumed all classes of people also used for culinary usage. Banana peels from about $18-33 \%$ of the whole fruit and are generally discarded as a waste product in large scale by banana crisp industries (Oliveir et al., 2008). Kapadia et al. (2015) also suggested that banana fruit peel has antibacterial activity against $P$. gingivalis and $A$. actinomycetemcomitans. This result opened up a new avenue for researchers to control of clinical pathogens with different varieties of banana fruit peel extracts. Previous studies suggested that powdered banana fruit peel also prevents bacterial attack by biosorption (a physical method of binding to bacteria) which makes it unavailable for binding to receptor sites of the oil glands of skin. Moreover banana fruit peel ash contains potent antioxidant compounds, such as vitamin A, vitamin C, and carotenoids (Arora et al., 2008), which has higher antioxidant activity (AA) than the pulp (Oliveir et al., 2008; Pereira, 2010), so it could be used to control the growth of pathogenic bacteria by disrupting cell membrane and also act as natural source of antiageing agent. Moreover, several endogenous antioxidant enzymes help in deactivating free radicals and maintains cellular functions. The study on total phenolic content (TPC) in banana peels revealed as high as accounting for $907 \mathrm{mg} / 100 \mathrm{~g}$ of dry sample (Someya $e t$ al., 2002), which is a well-known antimicrobial agent. Apart from that, banana peel also contains various minerals, such as potassium, calcium, sodium, iron, manganese and bromine which constitutes the high percentage of ash (8.9-12.95\%) (Anhwange et al., 2008), vitalise the skin. These properties of banana peel ascertained by studying the antibacterial activity of banana peel extract against acne causing Staphylococcus epidermidis and to confirm by biosorption and bioautography experiments. So, in view to exploit banana peel as a valuable source of cosmetic, the current study was undertaken to using it as a face mask to control the skin infection caused by acne causing bacteria.

\section{Materials and Methods}

Analytical grade fine chemicals used in the study and volumetric grade glassware procured from Cisco Research Laboratories Pvt. Ltd., Mumbai, India. Appropriately Sterilized chemicals and glassware were used under strict aseptic conditions throughout the study.

\subsection{Isolation and identification of acne causing $S$. epidermidis}

Swabs from acne infected person collected from Government Hospital, Coimbatore. For isolation of Staphylococcus epidermidis, collected sample incubated in trypticase soy broth (TSB) for $24 \mathrm{~h}$ at $37^{\circ} \mathrm{C}$. The isolated bacteria was serially sub-cultured for long-term storage and identified by standard microscopic observations, biochemical tests and species specific identification tests under aseptic conditions (Bruggmann et al., 2004).

\subsection{Preparation of banana peel extracts}

The peel of fresh, naturally ripened yellow un-pigmented banana fruit belonging to Musa sapientum collected, shade-dried for 7 days, then grinded to make a fine powder and sieved to collect powder with particle size of less than $0.4 \mathrm{~mm}$ in diameter. In separate, appropriately labelled flasks, the dried banana fruit peel powder weighed and mixed with $70 \%$ ethanol, $70 \%$ acetone and water at $1: 10 \mathrm{w} / \mathrm{v}$ ratio and extracted. Exhaustive extraction carried out in triplicates for about $36 \mathrm{~h}$ in shaker at $37^{\circ} \mathrm{C}$. The extracts were then evaporated to dryness at $28^{\circ} \mathrm{C}$. The residues obtained were re-evaporated to remove impurities and stored at $4^{\circ} \mathrm{C}$ (Valsaraj et al., 1997).

\subsection{Antibacterial susceptibility testing}

For mass culture of the organism, Staphylococcus epidermidis inoculated into sterile nutrient broth. After $24 \mathrm{~h}$ of incubation period at $37^{\circ} \mathrm{C}$, a loopful of inoculum transferred into $5 \mathrm{ml}$ of nutrient broth and incubated for $2 \mathrm{~h}$ at $37^{\circ} \mathrm{C}$. This serves as a fresh suspension of inoculum (Hayes and Markovic, 2002). On a sterile, MullerHinton agar plate swabbed with bacterial inoculum containing $10^{7}$ $\mathrm{CFU} / \mathrm{ml}$ of test bacteria and the wells of $5 \mathrm{~mm}$ diameter made using sterile cork borer. Then $40 \mu 1$ of banana peel extract poured into the wells. Controls set up with $40 \mu \mathrm{l}$ of sterile distilled water. The plates incubated at $37^{\circ} \mathrm{C}$ for $24 \mathrm{~h}$ and zones of inhibition around the wells measured in millimeters (mm) (Girish and Sathish, 2008).

\subsection{Determination of minimum inhibitory concentrations (MICs)}

Determination of the minimum inhibitory concentration (MIC) of the extracts carried out using the tube-dilution technique. A double fold serial dilution made for each extract using muller hinton broth (MHB). The following concentrations prepared; $1024 \mu \mathrm{g} / \mathrm{ml}, 512 \mu \mathrm{g} /$ $\mathrm{ml}, 256 \mu \mathrm{g} / \mathrm{ml}, 128 \mu \mathrm{g} / \mathrm{ml}, 64 \mu \mathrm{g} / \mathrm{ml}, 32 \mu \mathrm{g} / \mathrm{ml}, 16 \mu \mathrm{g} / \mathrm{ml}$ and $8 \mu \mathrm{g} / \mathrm{ml}$. About $0.1 \mathrm{ml}$ of standardized inoculum $\left(1.25 \times 10^{7} \mathrm{CFU} / \mathrm{ml}\right)$ added to each test tube. A tube containing $2 \mathrm{ml}$ of the broth and inoculum without extract served as control. The lowest concentration of the extracts which inhibited bacterial growth (no turbidity) recorded as the minimum inhibitory concentration (MIC).

\subsection{Biosorption experiments and bioautography}

To $50 \mathrm{ml}$ of bacterial culture broth mixed with $10 \mathrm{~g}$ of banana peel powder and agitated on an orbital shaker at a constant speed of 400 rpm for $1 \mathrm{~h}$. Then, the samples centrifuged for $5 \mathrm{~min}$ at $3500 \mathrm{rpm}$ and the supernatant of each sample analyzed for the remaining bacterial cell population at $660 \mathrm{~nm}$ using UV-Vis spectrophotometer. The difference between initial and final microbial mass concentrations considered to sorbed by the banana biomass (Hassan, 2013). The number of microbial cells adsorbed per unit mass of biomass calculated by using the following formula:

$$
\begin{aligned}
& \qquad \mathrm{C}_{\mathrm{e}}=\mathrm{Co}-\mathrm{Ct} \\
& \text { Adsorption \% }\left(\mathrm{q}\left(\mathrm{q}_{\mathrm{e}}\right)\right)=\frac{\mathrm{Co}-\mathrm{Ct}}{\mathrm{Co}} \times 100
\end{aligned}
$$

Sorption capacity at time $\mathrm{t} \mathrm{q}_{\mathrm{t}}(\mathrm{mg} / \mathrm{g})=(\mathrm{Co}-\mathrm{Ct}) \mathrm{X} \mathrm{V} / \mathrm{m}$

Sorption capacity at equilibrium $\mathrm{q}_{\mathrm{e}}(\mathrm{mg} / \mathrm{g})=(\mathrm{Co}-\mathrm{Ce}) \mathrm{X} \mathrm{V} / \mathrm{m}$ 
where $\mathrm{Co}(\mathrm{mg} / \mathrm{l})$ and $\mathrm{Ct}(\mathrm{mg} / \mathrm{l})$ were concentrations of solutes at the initial and a given time $\mathrm{t}$, respectively, $\mathrm{V}$ (liter) $=$ volume of solution of bacterial inoculums used, $\mathrm{m}(\mathrm{g})=$ amount of the biomass used.

Bioautography performed with bacterial cultures exhibiting high sensitivity to the extracts. The purified extracts loaded in TLC plate, developed with toluene, ethyl acetate $(95: 5, \mathrm{v} / \mathrm{v})$ and detected with sulfuric acid reagent. The plates run in duplicate, one set used as the reference chromatogram and the other used for bioautography. Developed TLC plates carefully dried for complete removal of solvent and $\mathrm{R}_{\mathrm{f}}$ values of the spots calculated. The spots on another TLC plate which not sprayed with detecting reagent at same $R_{f}$ collected by gentle scraping and overlaid on Muller-Hinton agar swabbed with the overnight broth culture of test bacteria and incubated at $37^{\circ} \mathrm{C}$ for $24 \mathrm{~h}$ (Kumar and Salma Khanam, 2004).

\subsection{Determination of total phenolic content (TPC)}

Total phenolic content of the banana peel extract estimated by Folin-Ciocalteu method, using gallic acid solution at $0-250 \mu \mathrm{g} / \mathrm{ml}$ concentrations as standard. Along with the standard, $250 \mu \mathrm{g} / \mathrm{ml}$ of banana peel extract analyzed in triplicates and phenolic content expressed as gallic acid equivalent. The outcome data expressed as $\mathrm{mg} / \mathrm{g}$ of gallic acid equivalents in dry banana peel powder (Aryal et al., 2019).

\subsection{Assay of antioxidant activity}

\subsubsection{DPPH radical scavenging assay}

The 2, 2-diphenyl-1-picrylhydrazyl (DPPH) scavenging activity measured by the spectrophotometric method. Different concentrations (10-100 $\mu \mathrm{g} / \mathrm{ml})$ of acetone extract of banana fruit peel powder dispensed in tubes having $1.6 \mathrm{ml}$ of methanol, mixed with $2.4 \mathrm{ml}$ of $0.1 \mathrm{mM}$ DPPH in methanol solution. The absorbance (Abs) of DPPH diluted in methanol considered as control. The decrease in absorbance measured after 30 min of incubation in dark at $517 \mathrm{~nm}$ and the percentage of inhibition $\left(\mathrm{IC}_{50}\right)$ calculated from the plotted graph (Rahman et al., 2015). The antioxidant capacity to scavenge the DPPH radical calculated using the following equation:

DPPH scavenging effect $(\%)=$

$(($ Abs of control/Abs of sample $) /$ Abs of the control $) \times 100$.

\subsubsection{ABTS radical-cation scavenging assay}

To $7 \mathrm{mM}$ solution of 2,22 -azino-bis(3-ethylbenzo-thiazoline-6sulfonic acid diammonium salt (ABTS) allowed to react with the $2.45 \mathrm{mM}$ ammonium persulphate solution to produce a dark coloured solution containing ABTS radical cations. The initial absorbance measured at $734 \mathrm{~nm}$. This stock solution diluted with methanol to give a final absorbance value and equilibrated at $23^{\circ} \mathrm{C}$. The decrease in absorbance measured exactly one minute after mixing the solution up to six minutes (Morales and Paredes, 2014). The final absorbance noted. The percentage inhibition calculated from the plotted graph and percentage of scavenging activity calculated according to the following formula:

ABTS scavenging $\%=$

$(($ Abs of control/Abs of sample $) /$ Abs of the control $) \times 100$.

\section{Results}

\subsection{Isolation and identification of pathogen}

Three different acne sample swabs collected of acne lesions from patients in the age group of $15-18$ years. The swabs incubated in nutrient broth media for $24 \mathrm{~h}$ at $37^{\circ} \mathrm{C}$. Heavy turbidity within $14 \mathrm{~h}$ of incubation recorded. Inoculum sub-cultured on nutrient agar plates to isolate the pathogen. On an agar culture plate small, entire, cream coloured colonies obtained.

The isolate identified by microscopic observation as Gram-positive, spherical bacteria arranged in clusters and negative for motility, oxidase test, coagulase test and DNase test and positive for growth on Mannitol Salt agar but mannitol not fermented thereby produced pink colour colonies and galactose, nitrate reduction, urease test, Voges Proskaeur test positive. From the morphological and biochemical tests may belong to Staohylococcus epidermidis (Langlois et al., 1990), the member of Firmicutes, and is often found in the nose, respiratory tract and the skin (Figure 2) and also an aerobic and normal inhabitant of the lower reproductive tract.

\subsection{Preparation of banana peel powder and extracts}

The peel of fresh, naturally ripened yellow un-pigmented banana shade-dried for about 6 days and then crushed to make a fine powder. From $20 \mathrm{~g}$ (wet weighted) of banana peel around $10 \mathrm{~g}$ of dried powder obtained (Figure 1). The dried powder $(10 \mathrm{~g})$ weighed and extracted using the solvents like $50 \mathrm{ml}$ of $10 \%$ concentrations of ethanol, acetone, and water. From $10 \mathrm{~g}$ of powder $1.2 \mathrm{~g}, 1.5 \mathrm{~g}$, and $2.3 \mathrm{~g}$ of dried extract in the form of powder obtained, respectively.

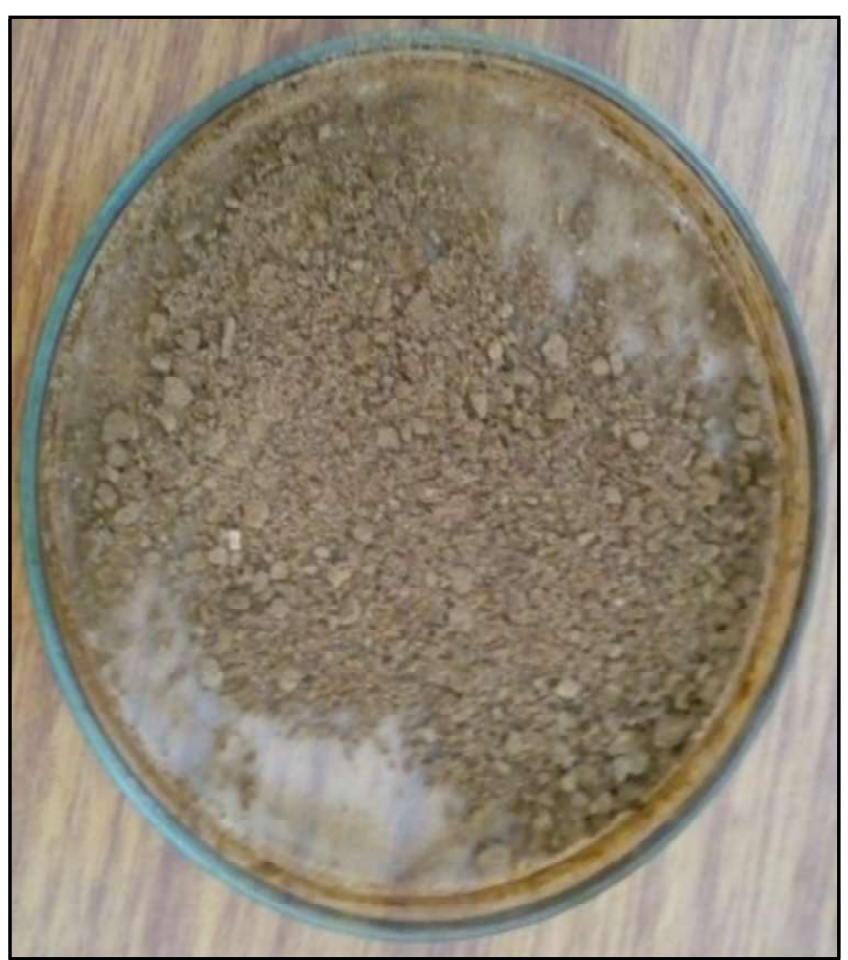

Figure 1: Dried banana fruit peel powder. 


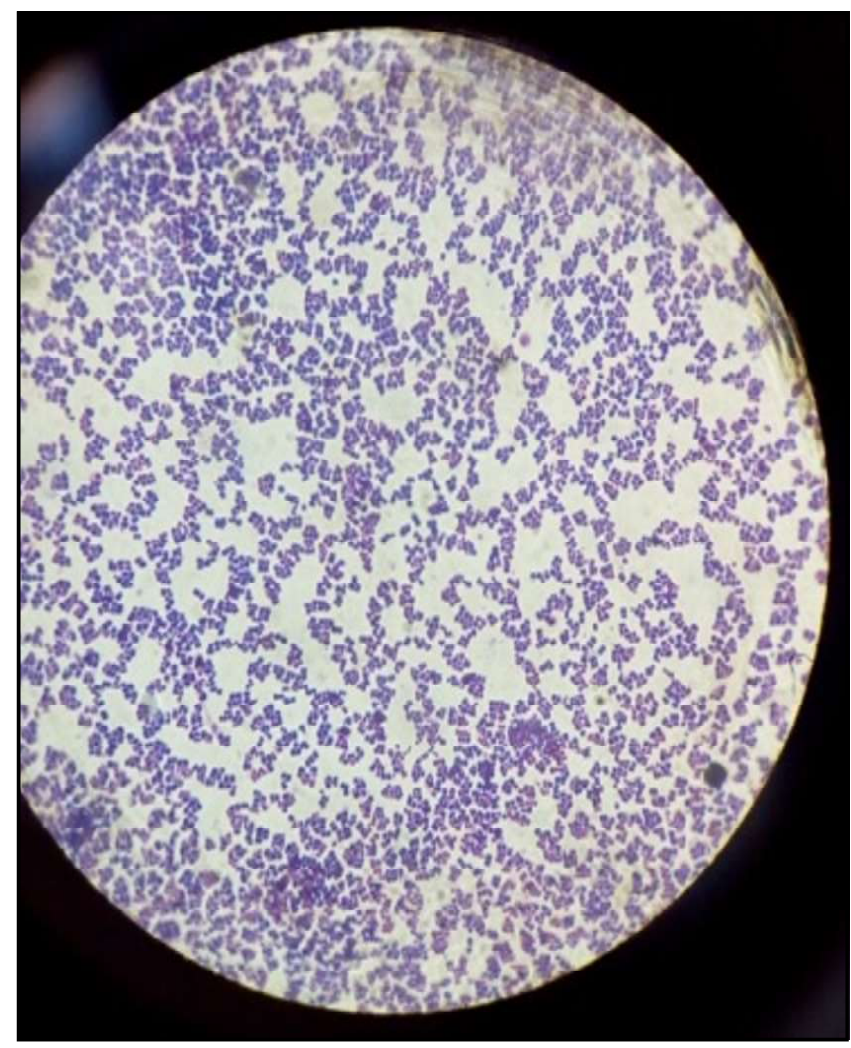

Figure 2: Microscopic examination of S. epidermidis.

\subsection{Antibacterial activity of fruit peel}

The maximum antibacterial activity against Staphylococcus epidermis resulted in $17 \mathrm{~mm}$ diameter of zone of inhibition on muller-hinton agar (MHA). The minimum inhibitory concentration (MIC) of the extract determined as $32 \mu \mathrm{g} / \mathrm{ml}$ (Figure 3 ).

\subsection{Analysis of biosorption}

Microbial cells mixed with the banana peel extract and percentage of reduction in microbial cells from the initial OD of $1.02\left(\mathrm{C}_{\mathrm{o}}=1 \mathrm{X}\right.$ $\left.10^{6} \mathrm{CFU} / \mathrm{ml}\right)$ reduced to $0.32\left(\mathrm{C}_{\mathrm{t}}=3 \times 10^{5} \mathrm{CFU} / \mathrm{ml}\right) \mathrm{OD}$. The difference between initial and final concentration considered as sorbed by the banana biomass (Figure 4).

$$
\begin{gathered}
\mathrm{C}_{\mathrm{e}}=C o-C t=1000000-300000=700000 \\
\text { Adsorption } \%\left(\mathrm{q}\left(\mathrm{q}_{\mathrm{e}}\right)\right)=\frac{1000000-300000}{1000000} \times 100=70 \% \\
\text { Sorption capacity at time } \mathrm{t} \mathrm{q}_{\mathrm{t}}(\mathrm{mg} / \mathrm{g})= \\
(1000000-30000) \times 0.05 / 10=3500 \mathrm{CFU} / \mathrm{ml}
\end{gathered}
$$

Sorption capacity at equilibrium $\mathrm{q}_{\mathrm{e}}(\mathrm{mg} / \mathrm{g})=$ $(1000000-700000) \times 0.05 / 10=1500 \mathrm{CFU} / \mathrm{ml}$

The biosorption of the peel powder means the percentage of reduction of bacterial population of $70 \%$. The rate of sorption of bacteria determined as $3500 \mathrm{CFU} / \mathrm{ml}$. So, the study indicated that the banana peel extract reduced the bacterial cells also by adsorbing to the bacterial cells.

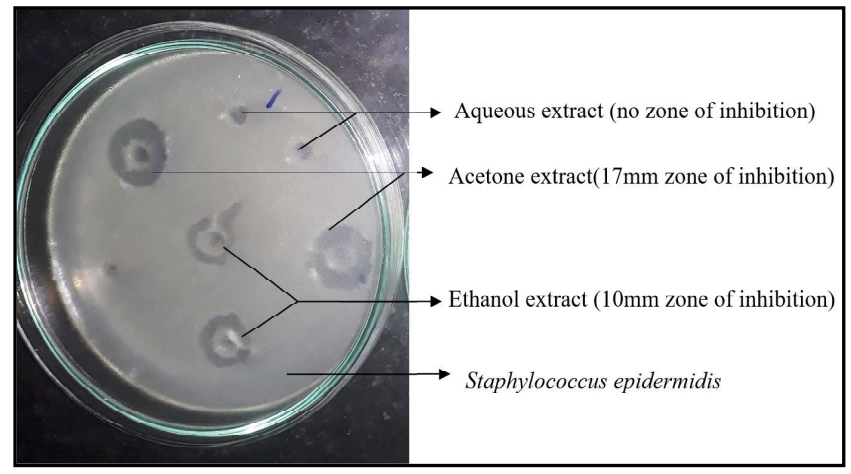

Figure 3: Antimicrobial activity of banana peel extracts on MullerHinton agar.

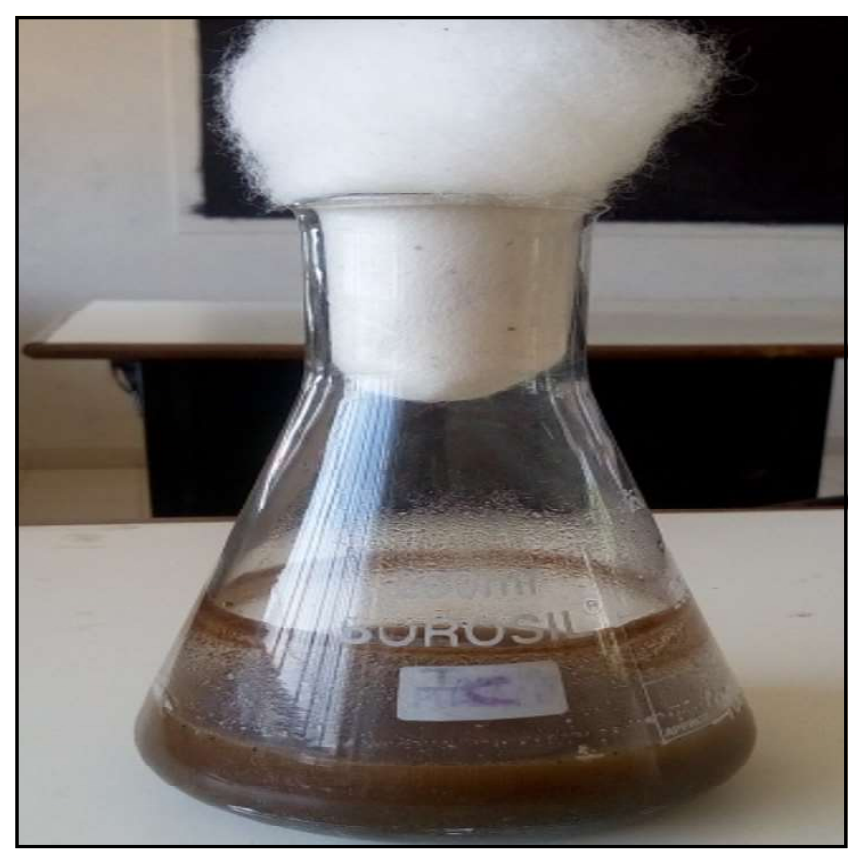

Figure 4: Biosorption assay.

\subsection{Bioautography}

In order to find the principle compound that inhibiting the bacterial cells, the extract run on a solid phase. Formation of two different bands indicated the presence of alkaloids and their antibacterial activity confirmed. Each compound inhibited the growth of bacteria by $21 \mathrm{~mm}$ and $24 \mathrm{~mm}$ on MHA and control showed absence of zone of inhibition. Above studies indicated that the banana peel powder is very efficient in controlling the growth of acne causing bacterial Staphylococcus epidermis by both inhibiting its growth and biosorbance, due to that it can prevent the establishment of bacterial pathogen (Figures 5 and 6).

\subsection{Total phenolic content in banana peel extract}

The phenolic content present in the extract reacts with the Folin Ciocalteu reagent and produced blue colour compound due to the reduction of phosphotungstic acid and phosphomolybdic acid, which was measured at $750 \mathrm{~nm}$. The concentration of phenols determined from the standard curve plotted for the gallic acid values as $31.56 \pm 0.21 \mathrm{mg} / \mathrm{g}$ of dry banana peel extract. 


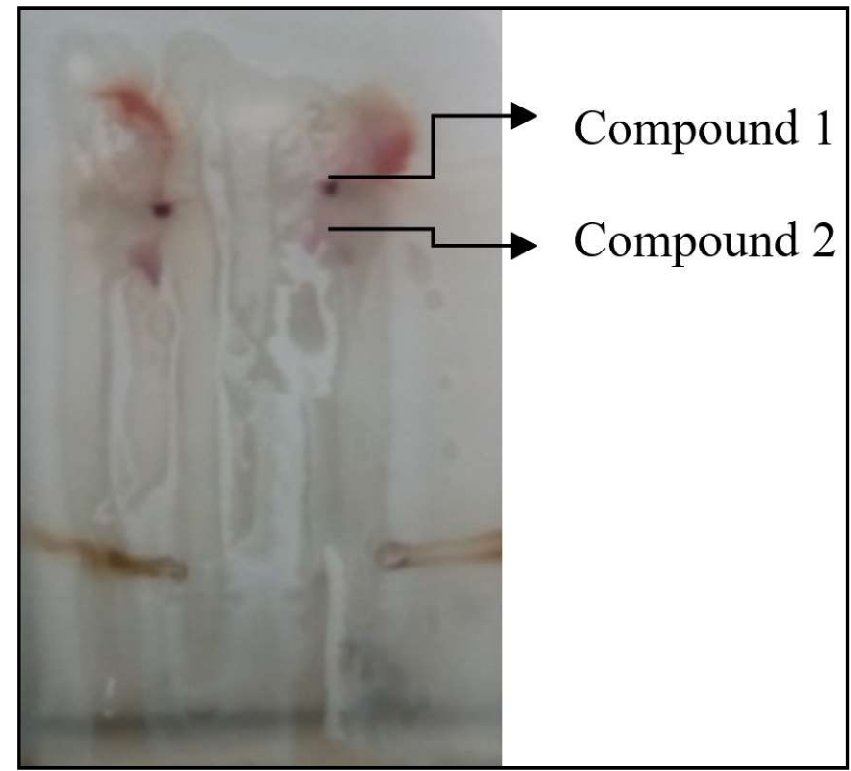

Figure 5: TLC plate with band for alkaloids.

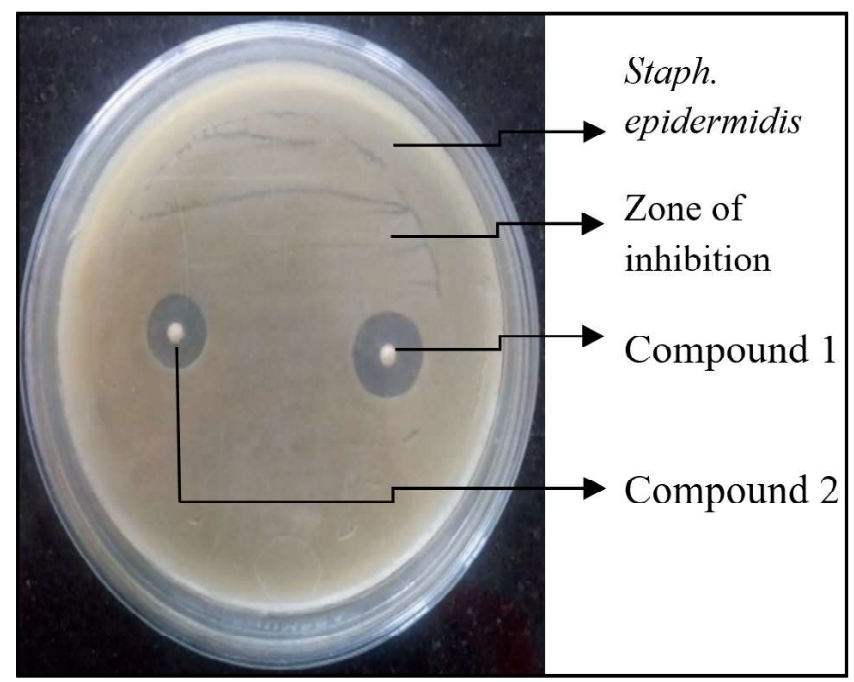

Figure 6: Bioautography of banana fruit peel extract.

\subsection{Antioxidant activity of banana peel extract}

The acetone extract of banana peel extract efficiently scavenged the free radical produced from the DPPH and ABTS reagents. When concentrations of extract increased from $10 \mu \mathrm{g} / \mathrm{ml}$ to $100 \mu \mathrm{g} / \mathrm{ml}$, free radical scavenging activity increased proportionately. Maximum antioxidant activity recorded at $100 \mu \mathrm{g} / \mathrm{ml}$ of extract as $71.21 \pm 0.91$ and $86.78 \pm 0.88$ by DPPH and ABTS method, respectively. From the exploited value of the Figure $1, \mathrm{IC}_{50}$ determined as $36.2 \%$ and $44.6 \%$ in DPPH and ABTS method, respectively, which confirms the higher redox potential and antioxidant property of the extract. According to the recorded results, around $40 \%$ of radical scavenging activities calculated. The decrease in radical ions to $40 \%$ substantiates the potential of banana peel extract to optimize proper cellular activity in cells by elimination of free radicals (Table 1; Figure 7).

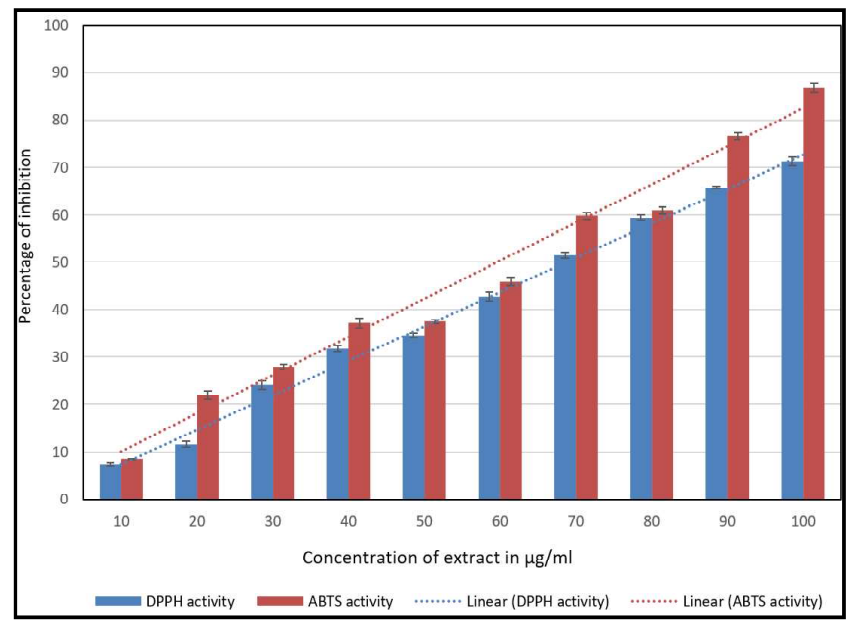

Figure 7: Antioxidant activity of banana peel extract.

Table 1: Antioxidant activity of banana peel extract

\begin{tabular}{|c|c|c|}
\hline \multirow{2}{*}{$\begin{array}{c}\text { Concentration } \\
\text { of extract } \\
(\mu \mathrm{g} / \mathrm{ml})\end{array}$} & \multicolumn{2}{|c|}{ Percentage of inhibition } \\
\hline & $\begin{array}{c}\text { DPPH scavenging } \\
\text { activity }\end{array}$ & $\begin{array}{c}\text { ABTS scavenging } \\
\text { activity }\end{array}$ \\
\hline $\begin{array}{l}10 \\
20 \\
30 \\
40 \\
50 \\
60 \\
70 \\
80 \\
90 \\
100 \\
\mathrm{IC}_{50}\end{array}$ & $\begin{aligned} & 7.41 \pm 0.36 \\
& 11.68 \pm 0.57 \\
& 24.17 \pm 0.89 \\
& 31.86 \pm 0.62 \\
& 34.71 \pm 0.48 \\
& 42.78 \pm 0.94 \\
& 51.49 \pm 0.61 \\
& 59.44 \pm 0.54 \\
& 65.76 \pm 0.22 \\
& 71.21 \pm 0.91 \\
& 36.2 \%\end{aligned}$ & $\begin{aligned} & 8.66 \pm 0.06 \\
& 22.10 \pm 0.88 \\
& 27.99 \pm 0.50 \\
& 37.12 \pm 0.96 \\
& 37.43 \pm 0.34 \\
& 45.95 \pm 0.87 \\
& 59.77 \pm 0.66 \\
& 60.92 \pm 0.72 \\
& 76.61 \pm 0.70 \\
& 86.78 \pm 0.88 \\
& 44.6 \%\end{aligned}$ \\
\hline
\end{tabular}

\section{Discussion}

Banana is a nutritional fruit. The peel of banana considered as typical waste after consumption, which disposed by banana chip industries. All parts of the banana plant used for its medicinal property, including the banana peel. Its hallucinogenic effect proven from its burnt product. Fibres, phenolics, tannins, saponins, alkaloids, steroids, flavonoids and carbohydrates play major role in its properties.

Acne vulgaris is a most common, chronic disorder of the pilosebaceous unit, caused by the clogging of skin follicles by the deposition of oil and dead skin cells, which leads to proliferating microbial growth. That affected area containing the largest oil glands, including the face, back, and trunk. It is generally characterized by formation of seborrhea, inflammatory lesions and the presence of bacteria Staphylococcus epidermidis, Propionibacterium acne and Malassezia furfur, in the follicular anal and results in sebum production (Arora et al., 2008; Pereira, 2010). Staphylococcus epidermidis an aerobic organism, usually involves in superficial infection within the sebaceous unit. Application of chemicals to treat skin infections leads to deliberate ill effect on the face such as rashes and damage the skin cells or causes premature death of facial cells. Biocompatible products are preferred mostly for application 
on the face. Aloe vera and fruits based skin ailment are commercialized, but not have phenolic content like banana peel. So for treatment of acne, banana peel extract evaluated in the present study.

The waste, ripened banana peels collected and shade dried. The phytochemical constituents of peel extracted with $10 \%$ of organic solvents of $70 \%$ ethanol, $70 \%$ acetone and water. Antimicrobial activity of extracts analyzed against the pathogens Staphylococcus epidermidis which isolated from acne sample and species confirmed by biochemical tests. The residues obtained by extractions yielded $1.2 \mathrm{~g}$ by acetone, $1.5 \mathrm{~g}$ by ethanol, and $2.3 \mathrm{~g}$ by water. The collected extract subjected to antimicrobial assay by well diffusion assay on nutrient agar plates and Muller Hinton agar plates against Staphylococcus epidermidis and in nutrient broth for MIC. After incubation, the pathogen inhibited by producing a maximum zone of inhibition of $15 \mathrm{~mm}$ on nutrient agar and $17 \mathrm{~mm}$ on Muller Hinton Agar by acetone extract as it consists of many active phytochemical compounds than the water extract (Kapadia et al., 2015). Other extracts showed less than $10 \mathrm{~mm}$ of zone of inhibition, so for the further analysis acetone extract selected. Acetone is the low polarity solvent than methanol and so used for complete extraction of alkaloids with its fatty tail. Minimum inhibitory concentration of the acetone extract against the select pathogen determined by the tube-dilution method as $32 \mu \mathrm{g} / \mathrm{ml}$. So as the antibacterial activity of banana extract confirmed. A similar study conducted by Kapadia et al. (2015) on antibacterial activity of banana peel extract against Porphyromonas gingivalis and Aggregatibacter actinomycetem comitans by agar well diffusion technique, confirmed antimicrobial activity by $15 \mathrm{~mm}$ and $12 \mathrm{~mm}$ zone of inhibition against an alcohol extract of purified banana peel, respectively. Recorded results of this research work highlight the fact that the organic solvent (acetone) extracts especially hydroxyl group containing solvents exhibited greater antibacterial activity because of the antimicrobial principles extracted with either polar or non-polar solvents and can be extracted more or only through the organic solvent medium. This observation agrees with the report of other investigators of medicinal plants that organic solvents are more suitable for extraction of phytochemicals (Singh and Bhat, 2003; Natarajan et al., 2005). The acetone fractions of banana peel displayed high antimicrobial and antioxidant activity. The antioxidant potential of many medicinal plants helps in the neutralization of oxidative damage, caused by free radicals and free oxygen species, formed in the cells formed during microbial infections and inflammation. For neutralization, use of these plants in food has vital importance in our body by the maintenance of human health and prevention of oxidative-stress related disease (Ijinu, et al., 2016). Due to that, nowadays food supplements and pharmaceutical industries are particularly enriched their products with synthetic antioxidants, which may lead to unwanted toxic-side effects to human health (Sevgi Gezici et al., 2020). Antioxidant activity of water extracts of phytochemicals are more distinct and more comparable to those of commonly used, synthetic antioxidants such as butylated hydroxyanisole and butylated hydroxytoluene. Similar antimicrobial studies confirmed that organic solvent of banana fruit peel consists of $\beta$-sitosterol, malic acid, succinic acid, palmatic acid, 12-hydroxystrearic acid, glycoside, the d-malic and 12-hydroxystrearic acid were the most active against all the Gramnegative and positive bacterial species including different species of Staphylococcus sp., while water extract showed minimum antimicrobial activity with maximum antioxidant potential (Mokbel and Hashinage, 2005).

The biosorption experiment based on the particles size and shape, surface morphology as well as a specific surface area of biosorbant fully depends on the preparation method. In addition, biosorbants are easy to prepare and use. When bacterial culture mixed with $20 \%$ of banana fruit peel powder, absorbed $70 \%$ of the cells. Biosorption studies carried out for removal of metals from the polluted environment. Natural products usually considered waste, such as sugar cane bagasse, peanut shells, and apple waste, employed to extract metals from water by biosorption. Biosorption property in these peel rendered by the presence of acid groups such as carboxylic and phenolic groups in the peel. Similarly, the bacteria also adsorbed by the banana fruit peel powder due to surface charges on the cell. Hence, the banana fruit peel based biosorption is a favorable alternative for removal of Staphylococcus sp., from skin (Ho and Ofomaja, 2006).

The evolution and spread of new drug resistance strains of infectious pathogens are a great concern globally. So, effective treatment relies on the development of novel pharmaceuticals. In several studies, organic extract of plants obtained from different parts, displayed a varying degree of antibacterial activity against various human pathogens. GC/MS analysis also confirmed the presence of some of the antimicrobial phytochemicals in higher concentrations such as esters, phytol, sialic acid, undec-2-enyl ester, trichloroacetic acid, tetraethyl silicate, benzeneethanol $\alpha-\alpha-\beta-$ triphenyl and 2-pNitrophenylOxadiazol-1,3,4one-5 (Anjaneyulu Musini et al., 2013). Other phytochemical components such as alkaloid are responsible for antibacterial activity analysed by TLC method. Development of two coloured spots indicated the presence of alkaloids. The separated alkaloids scrapped off from the TLC plate and antibacterial activity of each confirmed as $21 \mathrm{~mm}$ and $24 \mathrm{~mm}$ by bioautography experiment. In general, presence of secondary metabolites in plants responsible for antibacterial activity. Secondary metabolites include flavonoids, tannins, phlobatannins, alkaloids, glycosides, and terpenoids in the banana fruit peel (Imam and Akter, 2011). The antibacterial activity of the crude sample improvised upon purification of the product and interferes with the ATPdependent transport of compounds across the cell membrane. Alkaloids are more active on Staphylococcus sp., than other Gramnegative bacteria by affecting its ATP-dependent efflux pump (Donald et al., 2016).

Phytochemical analysis results showed the presence of $31.56 \pm$ $0.21 \mathrm{mg}$ gallic acid equivalent of phenol/g of dry banana peel extract of phenols, which already proven is known for a pivotal role as the effective disinfectant to control all kinds of microbial populations. As phenol readily dissolves in organic solvents, so acetone extracted the total phenols and showed maximums activity. Previous research studies proved the presence of $3.6 \pm 0.089 \mathrm{mg} \mathrm{GAE} / \mathrm{g}$ of total phenol in different extracts of plants and especially in banana peel total phenolics ranged between $9.89 \pm 0.16$ and $35.06 \pm 0.19 \mathrm{mg}$ $\mathrm{GAE} / 100 \mathrm{~g}$ of dry banana peel extracted using polar to non-polar solvents (Anal et al., 2014; Aryal et al., 2019; Ahmed M. Aboul Enein et al., 2016). Current study results revealed the presence of high concentration of phenols by acetone extraction from banana peel. 
Antioxidant of the extract increased with increasing concentration of the extract revealed prospective to remove free radical formed during cellular metabolism or inflammation resulting in cellular aging and senescence of the human cells. So, facial application of banana peel has the property to inhibit or kill the pathogenic microbial population on the skin, meanwhile improve the vigour of the human cells by its radical quenching ability. The maximum antioxidant activity determined at $100 \mu \mathrm{g} / \mathrm{ml}$ of extract as $71.21 \pm 0.91$ and $86.78 \pm 0.88$ and $\mathrm{IC}_{50}$ determined as $36.2 \%$ and $44.6 \%$ in DPPH and ABTS method, respectively. Extraction with acetone considered as the suitable solvent for complete extraction of antioxidants from banana peel powder. The proportionate increase in antioxidant ability of the banana peel extract indicated immediate the ability to remove free radicals, oil, lipid and cholesterols from skin and protects from bacterial attack on skin and oil glands. Presence of glycosides and alkaloids in Musa sapientum fruit peels attributed to their use of traditional medicine (Ehiowemwenguan et al., 2006). So, instead of aiming for artificial antimicrobial agents, cleanser and vitalizing agents, banana peel can be considered as the efficient and safe agent for facial applications. As banana peel is having biosorption property, high biocompatible phenolic content and antibacterial alkaloids recommended for facial application and can prevent the establishment of skin infection causing bacteria after addressing ethical issues. So, a cheap and efficient medicine from the banana fruit peel recommended for treatment of acne.

\section{Conclusion}

Banana peel is a cheap waste material available throughout the year in India. The current study proved the presence of antibacterial phenolics and alkaloids in the peel, especially against acne causing bacteria Staphylococcus epidermidis. Moreover, confirmed antioxidant property prevents early maturation of skin and prevent from ageing. So, the banana peel mash is strongly recommended as a skin protective agent after addressing ethical issues.

\section{Acknowledgements}

We thank the Microbiology Department of Sree Narayana Guru College, Rathnavel Subramaniam College and Dr. NGP College of Arts and Science for the support to complete the research work successfully.

\section{Conflict of interest}

The authors declare that there are no conflicts of interest in the course of conducting the research. All the authors had final decision regarding the manuscript and decision to submit the findings for publication.

\section{References}

Ahmed M. Aboul Enein; Zeinab A. Salama; Alaa A. Gaafar; Hanan F. Aly; Faten A bou Elella, and Habiba A. Ahmed. (2016). Identification of phenolic compounds from banana peel Musa paradaisica 1 as antioxidant and antimicrobial agents. Journal of Chemical and Pharmaceutical Research, 8(4):46-55.

Anal, A. K.; Jaisanti, S. and Noomhorm, A. (2014). Enhanced yield of phenolic extracts from banana peels (Musa acuminata Colla AAA) and cinnamon barks (Cinnamomum varum) and their antioxidative potentials in fish oil. Journal of Food Science and Technology, 51(10): 2632-2639. https://doi.org/10.1007/s13197-012-0793-x
Anhwange, B.A.; Ugyeans, T.J.; Nyiaatagher, T, D. (2008). Chemical composition of Musa sapientum (Banana) peels. EJEAF Che., 8:437-442.

Anjaneyulu Musini; Jayaram Prakash Rao M. and Archana Giri. (2013). Phytochemical investigations and antibacterial activity of Salacia oblonga Wall ethanolic extract. Ann. Phytomed., 2(1):102-107.

Arora, A.; Choudhary, D.; Agarwal, R. and Singh, V.P. (2008). Compositional variation in $\beta$-carotene content, carbohydrate and antioxidant enzymes in selected banana cultivars. J. Food Sci. Technol., 43: 1913-1920.

Aryal, S.; Baniya, M.K.; Danekhu, K.; Kunwar, P.; Gurung, R.; and Koirala, N. (2019). Total Phenolic Content, Flavonoid Content and Antioxidant Potential of Wild Vegetables from Western Nepal. Plants (Basel). 8(4):96. doi:10.3390/plants 8040096

Bruggemann, H.; Henne, A.; Hoster, F.; Liesegang, H.; Wiezer, A. and Strittmatter, A. (2004). The complete genome sequence of Propionibacterium acnes, a commensal of human skin. Science, 305:671-673.

Donald Mabhiza; Tariro Alison Chitemerere and Stanley Mukanganyama (2016). Antibacterial Properties of Alkaloid Extracts from Callistemon citrinus and Vernonia adoensis against Staphylococcus aureus and Pseudomonas aeruginosa. International Journal of Medicinal Chemistry, (1):1-7. ID 6304163. https://doi.org/10.1155/2016/ 6304163

Ehiowemwenguan, G.; Emoghene, A.O. and Inetianbor, J.E. (2006). Antibacterial and phytochemical analysis of Banana fruit peel. IOSR J. Pharm., 4(8): $18-25$.

Girish, H.V. and Satish, S. (2008). Antibacterial activity of important medicinal plants on human pathogenic bacteria: A comparative analysis, World Application of Science Journal, 5(3):267-271.

Hassan, W. (2013). Potential biosorbent, Haloxylon recurvum plant stems, for the removal of methylene blue dye. Arabian Journal of Chemistry, 2(1):03-11.

Hayes, A.J. and Markovic, B. (2002). Toxicity of Australian essential oil Backhousia citriodora (Lemon myrtle) Part 1. Antimicrobial Activity and in vitro Cytotoxicity, 40:535-543.

Ho, Y.S. and Ofomaja, A.E. (2006). Biosorption thermodynamics of cadmium on coconut copra meal as biosorbent. Biochemical Engineering Journal, 30(2):117-123.

Ijinu, T.P.; Latha, P.G.; George, V. and P. Pushpangadan. (2016). Total phenolic and flavonoid contents and in vitro antioxidant potential of methanolic extract of Blepharis maderaspatensis (L.) B. Heyne ex Roth. whole plant. Ann. Phytomed., 5(1):85-90.

Imam, M.Z. and Akter, S. (2011). Musa paradisiaca L and Musa sapientum L: A phytochemical and pharmacological review. J. App. Pharm. Sci., 11(1):14-20.

Kapadia, S.P.; Pudakalkatti, P.S. and Shivanaikar, S. (2015). Detection of antimicrobial activity of banana peel (Musa paradisiaca L.) on Porphyromonas gingivalis and Aggregatibacter actinomycetemcomitans: An in vitro study. Contemporary Clinical Dentistry, 6(4):496-499.

Kashyap, P.; Anand, S. and Abhimanyu Thakur. (2017). Evaluation of antioxidant and antimicrobial activity of Rhododendron arboreum flowers extract. International Journal of Food and Fermentation Technology, 7(1):123-128.

Kumar, G.S. and Salma Khanam. (2004). Antiacne activity of few natural products. Ind. J. Nat Prod., 30(4):7-9. 
Langlois, B.E.; Parlindungan, A.K.; Harmon, R.J. and Akers, K. (1990). Biochemical characteristics of Staphylococcus species of human and bovine origin. Journal of Food Protection, 3:119-126.

Mokbel, M.S. and Hashinage, F. (2005). Antioxident activities of banana (Musa, A Cavendish) fruits peel. American journal of Biochemistry and Biotechnology, 1(3):125-131.

Morales, G. and Paredes, A. (2014). Antioxidant activities of Lampaya medicinalis extracts and their main chemical constituents. BMC Complementary and Alternative Medicine, 14:259. https://doi.org/ 10.1186/1472-6882-14-259

Natarajan, D.; Britto, J.S.; Srinivasan, K.; Nagamurugan, N.; Mohanasundari, C. and Perumal, G. (2005). Antibacterial activity of Euphorbia fusiformis: A rare medicinal herb. Journal of Ethnopharmacology, 102:123-126.

Oliveira, L.; Freire, C.S.; Silvestre, A.J. and Cordeiro, N. (2008). Lipophilic extracts from banana fruit residues: A source of valuable phytosterols. J. Agric. Food Chem., 56(20):9520-9524.

Pathak, P. (2020). Medicinal properties of fruit and vegetable peels. In: Vyas R. (eds) Advances in Bioengineering. Springer, Singapore. https://doi.org/10.1007/978-981-15-2063-1_6

Pereira, A. (2010). Avaliação das atividades cicatrizante e antitumoral de extratos provenientes da casca de banana cultivar Prata Anã Musa spp Dissertação (Mestrado em Biotecnologia). Universidade Federal de Santa Catarina, Florianópolis, 2:78.
Rahman, M.M.; Islam, M.B.; Biswas, M. and Kurshid Alam A.H, M. (2015). In vitro antioxidant and free radical scavenging activity of different parts of Tabebuia pallida growing in Bangladesh. BMC Res. Notes, 8:621. https://doi.org/10.1186/s13104-015-1618-6

Sevgi Gezici, Didem Koçum, Fatih Yayla, Nazim Sekeroglu and Adnan A. Khan. (2020). Screening for in vitro antioxidant activities, polyphenolic contents and neuroprotective potentials of Clinopodium serpyllifolium subsp. serpyllifolium endemic to Turkey. Ann. Phytomed., 9(1):181-186. http://dx.doi.org/10.21276/ap.2020.9.1.23

Singh, B. and Bhat, T.K. (2003). Potential therapeutic applications of some anti-nutritional plant secondary metabolites. Journal of Agriculture and Food Chemistry, 51:5579-5597.

Someya, S.; Yoshiki, Y. and Okubo K. (2002). Antioxidant compounds from bananas (Musa cavendish). Food Chemistry, 79:351-354.

Upadhyay, A.; Upadhyaya, I.; Kollanoor Johny, A. and Venkitanarayanan, K. (2014). Combating pathogenic microorganisms using plant-derived antimicrobials: A minireview of the mechanistic basis. BioMed Research International, pp:761741. https://oi.org/10.1155/2014/ 761741

Valsaraj, R.; Pushpangadan, P. and Smitt, U.W. (1997). Antimicrobial screening of selected medicinal plants from India. J. Ethnopharmacol, 58:75-83.

Citation P. Saravana Kumari, R. Ranjitha and N. Vidhya (2020). Revitalizing property of banana peel extracts by antioxidant activity and antibacterial activity against acne causing Staphylococcus epidermidis. Ann. Phytomed., 9(2):215-222. http://dx.doi.org/10.21276/ap.2020.9.2.19 